University of Nebraska - Lincoln

DigitalCommons@University of Nebraska - Lincoln

2010

\title{
Investigation of the fate and effects of acetyl cedrene on Capitella teleta and sediment bacterial community
}

\author{
Lea Ellegaard-Petersen \\ Copenhagen University, Leael@bio.ku.dk \\ Henriette Selck \\ Roskilde University \\ Anders Priemé \\ Copenhagen University \\ Daniel Salvito \\ Research Institute for Fragrance Materials, Woodcliff Lake, NJ \\ Valery E. Forbes \\ University of Nebraska-Lincoln, veforbes@umn.edu
}

Follow this and additional works at: https://digitalcommons.unl.edu/biosciforbes

Part of the Pharmacology, Toxicology and Environmental Health Commons

\footnotetext{
Ellegaard-Petersen, Lea; Selck, Henriette; Priemé, Anders; Salvito, Daniel; and Forbes, Valery E., "Investigation of the fate and effects of acetyl cedrene on Capitella teleta and sediment bacterial community" (2010). Valery Forbes Publications. 10.

https://digitalcommons.unl.edu/biosciforbes/10
}

This Article is brought to you for free and open access by the Papers in the Biological Sciences at DigitalCommons@University of Nebraska - Lincoln. It has been accepted for inclusion in Valery Forbes Publications by an authorized administrator of DigitalCommons@University of Nebraska - Lincoln. 


\title{
Investigation of the fate and effects of acetyl cedrene on Capitella teleta and sediment bacterial community
}

\author{
Lea Ellegaard-Petersen, ${ }^{1}$ Henriette Selck, ${ }^{2}$ Anders Priemé, ${ }^{1}$ Daniel Salvito, ${ }^{3}$ and Valery Forbes ${ }^{2}$ \\ 1. Department of Microbiology, Institute of Biology, Copenhagen University, Sølvgade 83H, 1307 Copenhagen K, Denmark \\ 2. Department of Environmental, Social and Spatial Change, Roskilde University, PO BOX 260, Universitetsvej 1, 4000 Roskilde, \\ Denmark \\ 3. Research Institute for Fragrance Materials, 50 Tice Boulevard, Woodcliff Lake, NJ 07677, USA
}

Corresponding author - Lea Ellegaard-Petersen, email Leael@bio.ku.dk

\begin{abstract}
The fate of the fragrance material, acetyl cedrene (AC), in sediment was examined in a 16 day laboratory experiment using the sediment microbial community subjected to the following treatments: AC (nominal concentration; 0 and $50 \mu \mathrm{g} \mathrm{g}{ }^{-1} \mathrm{dw}$ sediment) and macrofaunal worms (with/without Capitella teleta (formerly Capitella sp. I)). Furthermore effects of AC on microbial respiration in the system were determined by examining $\mathrm{CO}_{2}$ flux. T-RFLP (terminal restriction fragment length polymorphism) was used to analyze PCR (polymerase chain reaction) amplified 16S DNA gene fragments from the sediments to detect changes in the structure and diversity of the bacterial community. In addition, survival of $C$. teleta in sediment was determined. Lastly, we examined how the interactions between microbes and C. teleta in the sediment affected the above-mentioned parameters. The results showed that there was an interaction between worm treatment and time of sampling on the loss of AC from the sediment. This was caused by AC loss initially being fastest in the sediment with C. teleta present, but at experimental termination there was no significant difference between the two treatments (i.e., with/ without worms) in the amount of AC remaining in the sediment. Survival of C. teleta was significantly reduced by AC at experimental termination, but neither microbial respiration nor structure and diversity of the bacterial community were significantly affected.
\end{abstract}

Keywords: fragrance materials, sediment contamination, microbe-macrofauna interactions, bacterial community, TRFLP, ecological risk

\section{Introduction}

Fragrance materials are organic compounds (Aschmann et al. 2001) widely used in consumer products such as soaps, fabric softeners, cleaners, detergents, cosmetics, toiletries and perfumes (Bickers et al. 2003; Draisci et al. 1998). The primary route to the environment is through down-the-drain disposal of these products (Simonich et al. 2000, 2002). Fragrance materials have been found in wastewater in a number of wastewater treatment plants in Europe and the USA (Artola-Garicano et al. 2003b; Osemwengie and Gerstenberger 2004; Osemwengie and Steinberg 2001), and a few studies have detected acetyl cedrene (AC) (Simonich et al. 2000, 2002). The fate of fragrance materials in the aquatic environment can either involve sorption to particles and sedimentation, accumulation in aquatic organisms, (bio)degradation or volatilization to the atmosphere (Osemwengie and Gerstenberger 2004; Salvito et al. 2002). Other fragrance materials have been found in aquatic organisms such as mussels, clams and a number of fish species including eels (Draisci et al. 1998; Duedahl-Olesen et al. 2005; Franke et al. 1999; Fromme et al. 1999, 2001; Gatermann et al. 1999, 2002a, b; Osemwengie and Gerstenberger 2004; Osemwengie and Steinberg 2003) as well as in sharks, seals, otters, dolphins and porpoises (Kannan et al. 2005; Nakata 2005). However, AC has to our knowledge not been reported in aquatic organisms. 
Chemical properties such as solubility in water and octanol-water partitioning coefficients $\left(\mathrm{K}_{\mathrm{ow}}\right)$ of fragrance materials vary widely (Salvito et al. 2004). AC was chosen for this study based on a relatively high $\log \mathrm{K}_{\mathrm{ow}}$ (5.6-5.9), which causes AC to bind to sediment organic matter, and therefore provide a source of exposure to sediment-living organisms. The literature on AC effects on aquatic organisms is limited and consists largely of toxicology reports (Borgers 2001a, b, c, 2003a, b). These studies report NOECs (No Observed Effect Concentrations) in the range 0.087$0.68 \mathrm{mg} \mathrm{l}^{-1}$ for Daphnia magna and the algae Selenastrum capricornutum, respectively (Borgers 2001a, 2003a). Published studies on the toxic effects of AC on sediment organisms are at present lacking. Since sediments may act as a sink for AC, which is a high volume chemical compound with documented toxicological effects on pelagic organisms, such as Daphnia and phytoplankton, there is a pressing need for studying the fate and effects of this compound in the sediment compartment.

Sediment microorganisms are cosmopolitan, carry out a number of specific functions in ecosystems, constitute an important food source for macrofauna, and play a key role in the degradation of organic chemicals (Van Beelen and Doelman 1997). Many different methods have been applied to examine the effects of chemicals on microbial communities in soils and sediments. These include studying the activity and respiration of the microbial community (Bauer et al. 1988; Capone et al. 1983; Holmer et al. 1997), substrate utilization using colony forming units counts or Biolog plates (Bååth et al. 1998; Klimek and Niklinska 2007), analysis of phospholipid fatty acid profiles (Bååth et al. 1998; Frostegård et al. 1993; Macnaughton and Stephen 2001), genetic analysis of bacterial community structure with denaturing gradient gel electrophoresis (DGGE) (Macnaughton and Stephen 2001; Petersen et al. 2004) or terminal restriction fragment length polymorphism (TRFLP) (Grant et al. 2007; Muckian et al. 2007; Paul et al. 2006). Most of these studies have examined the effects of either polycyclic aromatic hydrocarbons (PAHs) or heavy metals.

The sediment-dwelling polychaete Capitella teleta, formerly Capitella sp. I (Blake et al. 2009), was employed in this study. C. teleta is described as opportunistic and has a widespread distribution (Grassle 1980; Grassel and Grassel 1976) with population densities in the range of $<100-400,000$ worms $\mathrm{m}^{-2}$ (Méndez et al. 1997; Tsutsumi 1987, 1990). Several studies have examined the effects of chemical compounds on worm growth rate, sediment processing (Madsen et al. 1997; Méndez et al. 2001; Selck et al. 1998, 1999, 2003), mortality (Méndez 2006) and life-history traits (Linke-Gamenick et al. 1999, 2000a, b; Pedersen et al. 2009; Rams- kov et al. 2009). The interactions between Capitella and microbial activities (Alongi 1985) and degradation of chemicals in sediment (Gardner et al. 1979) have also been studied, where the presence of Capitella increased both of these parameters.

In the present study both the fate of $\mathrm{AC}$ and $\mathrm{AC}$ effects on the microbial community and C. teleta were examined. A laboratory experiment was carried out using sediment with a natural microbial community, which was spiked with AC. We examined the loss of AC from sediment with and without Capitella, as well as the effects of sediment-associated AC on C. teleta survival, microbial respiration, and bacterial community structure and diversity. In addition, we examined how interactions between microbes and macrofauna changed the degradation/loss of AC, microbial respiration, total sediment organic matter content, and bacterial community structure and diversity in the sediment.

\section{Methods and materials}

\section{Sediment collection and handling}

Sediment was collected in March 2007 from a shallow area in the inner part of Isefjorden, Denmark $\left(55^{\circ} 40^{\prime} 26 \mathrm{~N}, 11^{\circ} 48^{\prime} 52 \mathrm{E}\right)$. Samples were collected at this time to avoid the spring bloom of algae, and because bacteria therefore are assumed to dominate the microbial community in the sediment. The top few centimeters of the sediment surface were scraped off and sieved $(<250 \mu \mathrm{m})$ in seawater $(31 \%$ o $)$. The sediment was covered with seawater, supplied with air and kept in the dark at $17^{\circ} \mathrm{C}$.

\section{Sediment spiking}

Concentrations of sediment-associated AC in the experiment were 0 (i.e., control treatment) and $50 \mu \mathrm{g} \mathrm{AC} \mathrm{g}{ }^{-1} \mathrm{dw}$ sediment. We wanted to choose an exposure concentration that was high enough to cause some effects, but low enough to avoid mass mortality of worms or bacteria. $\mathrm{A} \mathrm{LC}_{50}$ for $\mathrm{AC}$ was calculated from a Quantitative Structure Activity Relationship according to Salvito et al. (2002) modified after Könemann (1981): $\mathrm{LC}_{50}=0.1\left(0.871 \times \log K_{\mathrm{ow}}+1.13\right) \times \mathrm{mol} \mathrm{wt} \times 10^{6}$. This gives a $\mathrm{LC}_{50}$ of $179.2 \mu \mathrm{g} \mathrm{l}^{-1}$ for $\mathrm{AC}\left(\mathrm{mol} \mathrm{wt}=246.4 \mathrm{~g} \mathrm{~mol}^{-1}\right.$; log $\mathrm{K}_{\mathrm{ow}}($ mean $\left.)=5.75\right)$. We decided to use an exposure concentration that was a factor of 3-4 lower than the predicted $\mathrm{LC}_{50}$ which was also supported by unpublished AC studies from our laboratory indicating some, but not extensive mortality at exposure concentrations of around $50 \mu \mathrm{g} \mathrm{AC} \mathrm{g}^{-1} \mathrm{dw}$ sediment. 
Prior to spiking, the sediment was prepared by mixing pre-frozen sediment $(<250 \mu \mathrm{m})$ with non-frozen sediment $(<125 \mu \mathrm{m})$ (approx. 1:1). The addition of non-frozen sediment was done to provide a source of active bacteria from the start of the experiment. The water content of the mixed sediment was 55.8\% $( \pm 0.84 ; n=3)$ $\left(24 \mathrm{~h}\right.$ at $\left.105^{\circ} \mathrm{C}\right)$, and the organic content was $2.6 \%( \pm 0.14$; $n=3)\left(6 \mathrm{~h}\right.$ at $\left.550^{\circ} \mathrm{C}\right)$. Stock sediment with a concentration of $500 \mu \mathrm{g} \mathrm{AC} \mathrm{g}{ }^{-1} \mathrm{dw}$ sediment was made by adding a known amount of liquid $\mathrm{AC}$ to a glass jar and then quickly adding a known amount of wet sediment. The glass jar was shaken overnight (in the dark at $17^{\circ} \mathrm{C}$ ) to ensure homogeneous contamination of the sediment. The control sediment $\left(0 \mu \mathrm{g} \mathrm{AC} \mathrm{g}{ }^{-1} \mathrm{dw}\right.$ sediment) received a similar handling. A final concentration of $50 \mu \mathrm{g} \mathrm{AC} \mathrm{g}^{-1} \mathrm{dw}$ sediment was made by mixing a known amount of wet stock sediment with a known amount of wet non-spiked sediment. The control sediment was prepared similarly. The glass jars were left on the shaking table overnight. Samples were taken from these concentrations $(n=3)$ and frozen $\left(-20^{\circ} \mathrm{C}\right)$ for later determination of the actual concentration of $\mathrm{AC}$ in the sediment. The samples were stirred by hand, each time they were used, to make sure that both the particle size distribution and the concentration of AC were as homogeneous as possible.

\section{Experimental setup}

Four treatments were applied: (1) with AC; with worms, (2) with AC; without worms, (3) without AC; with worms, and (4) without AC; without worms. Seven worms were added to each sample in the worm treatments to give a density of roughly 2000 worms $\mathrm{m}^{-2}$ in each crystallization beaker (diameter $=68 \mathrm{~mm}$ ), which is within the range of population densities found in the field (Méndez et al. 1997; Tsutsumi 1987, 1990). Fourteen replicate crystallization beakers were prepared for each of the four treatments. To each of these beakers $60 \mathrm{ml}$ of filtered $(0.2 \mu \mathrm{m})$ seawater $(31 \%)$ and $13 \mathrm{~g} \mathrm{dw}$ sediment (i.e., $23.3 \mathrm{~g} \mathrm{ww}$ sed) were added. The worms were taken from laboratory cultures of $C$. teleta. These had been reared in aerated aquaria with seawater $\left(31 \%\right.$ ) at $17^{\circ} \mathrm{C}$ on sediment and a food supplement of fish food (Tetra $\left.\operatorname{Min}^{\odot}\right)$, baby cereal $\left(\operatorname{Milpo}^{\odot}\right)$ and dried spinach in equal ratios (Selck and Forbes 2004).

Prior to assigning the worms to treatments they were grouped according to size (small, medium, large) to ensure an equal size distribution among treatments. Individual worms were photographed with a zoom stereo microscope (Olympus, SZ61-DP12, Tokyo, Japan) and worm body volumes $\left(\mathrm{V} ; \mathrm{mm}^{3}\right)$ were estimated from measurements of individual length $(\mathrm{L} ; \mathrm{mm})$ and area $\left(\mathrm{A} ; \mathrm{mm}^{2}\right)$, assuming worms are cylindrical in shape, using $V=\pi \mathrm{A}^{2} / 4 \mathrm{~L}$ (Self and Jumars 1978). Length and area were measured using an image analysis software program (Cell ${ }^{\mathrm{D}}$, Soft Imaging System, Münster, Germany). Subsequently, worms were randomly transferred into the beakers such that each replicate contained one small, three medium and three large worms. There was no significant difference in worm volume between the two worm treatments (i.e., with and without $\mathrm{AC})(p=0.763)$. All beakers were covered with parafilm and plexiglass to avoid evaporation during the experiment, and were placed in the dark at $17^{\circ} \mathrm{C}$ with a supply of air.

\section{Sampling and sediment/worm analyses}

Beakers were sampled on day $5(n=4$ per treatment), $10(n=4$ per treatment) and $16(n=6$ per treatment). Worms were gently sieved from the beakers (i.e., worm treatments), and sediment plus water were transferred to $100 \mathrm{ml}$ flasks (all treatments) for $\mathrm{CO}_{2}$ determination (see below). The sediments were subsequently transferred to glass vials and frozen $\left(-20^{\circ} \mathrm{C}\right)$ until $\mathrm{AC}$ and organic matter analysis. TOM (total organic matter) in the sediment was measured by weight loss on ignition $\left(550^{\circ} \mathrm{C}\right.$ for $\left.6 \mathrm{~h}\right)$. Samples from day 16 received the same handling, but in addition a small amount of sediment (3 g ww sed) was prepared for molecular analysis of the bacterial community in the sediment (see below). We increased the number of replicates to six on day 16 in order to increase statistical power as we expected a substantial spatial variability in the bacterial communities.

\section{$\mathrm{CO}_{2}$ flux}

The $\mathrm{CO}_{2}$ flux was determined to give an indication of the aerobic microbial activity in the system. The worms were removed from the sediments before these measurements were made. The $\mathrm{CO}_{2}$ flux was measured in the water phase just above the sediment, and it is assumed that this gives a good indication of the microbial activity in the sediment because of the exchange of gases between the sediment/water phases. The exchange rate of $\sum \mathrm{CO}_{2}$ from the sediment can be used as a measure of total benthic metabolism (i.e., the degradation rate of organic matter within the sediment) under dark incubation. From the water phase of the flasks, samples were taken to determine $\mathrm{CO}_{2}$ concentration at time $0-\left[\mathrm{CO}_{2}\right]$ $\mathrm{t}=0$. The flasks were sealed and placed on a shaking table in darkness at $17^{\circ} \mathrm{C}$ for $18 \mathrm{~h}$ (i.e., $\mathrm{t}=1$ ). Subsequently, water samples $(10 \mathrm{ml})$ were collected for determination of $\left[\mathrm{CO}_{2}\right]_{\mathrm{t}=1}$. The water samples were kept in $10 \mathrm{ml}$ exetainers $(10 \mathrm{ml}$ glass vials with airtight lids) until titration. The $\sum \mathrm{CO}_{2}$ concentration was determined by Gran titration (Stumm and Morgan 1981). Titration was performed with a piston burette (Titronic ${ }^{\circledR}$ basic, Schott Instruments, Mainz, Germany). A 5-ml subsample from 
the exetainer was transferred to a small cup. The $\mathrm{pH}$ cup was placed on a magnetic stirrer and $\mathrm{pH}$ was measured. If the initial $\mathrm{pH}$ was <7.6, $0.01 \mathrm{M} \mathrm{NaOH}$ (Merck, NJ, USA) was added until $\mathrm{pH}>7.6$. Titration was performed using $0.01 \mathrm{M} \mathrm{HCl}$ (Merck, NJ, USA) during gentle stirring with the tip of the burette submerged in the sample along with the $\mathrm{pH}$-meter. Three concurrent pairs of values of $\mathrm{pH}$ and volume of added titrant were determined in the $\mathrm{pH}$ range 7.6-6.6 $\left(\mathrm{v}_{1}\right)$. Titration was continued until a $\mathrm{pH}$ of approximately 4.4 was reached. Then three concurrent pairs of values of $\mathrm{pH}$ and titrant volume in the $\mathrm{pH}$ range 4.4-3.7 $\left(\mathrm{v}_{2}\right)$ were determined.

\section{Calculation of the $\mathrm{CO}_{2}$ flux}

$\sum \mathrm{CO}_{2}$ was calculated as follows: For data in the $\mathrm{pH}$ range 4.4-3.7 the following function was plotted: $\mathrm{F}_{1}=\left(\mathrm{v}_{0}+\mathrm{v}\right) 10^{-} \mathrm{pH} \times 10^{3}$, against the amount of added titrant, where $\mathrm{v}$ and $\mathrm{pH}$ are measured values: $\mathrm{v}=$ volume of added titrant $(0.01 \mathrm{M} \mathrm{HCl})$ in $\mathrm{ml}$ (after subtraction of the added volume of $\mathrm{NaOH}$ ) and $\mathrm{v}_{0}=$ volume of subsample $(\mathrm{ml})$. The intercept with the $x$-axis is $\mathrm{v}_{2}$. Data for the $\mathrm{pH}$ range $7.6-6.6 \mathrm{~F}_{2}=\left(\mathrm{v}_{2}+\mathrm{v}\right) 10^{-\mathrm{pH}} \times 10^{7}$, were plotted against the amount of added titrant. The intercept with the $x$-axis is $\mathrm{v}_{1}$. By use of $\mathrm{v}_{1}$ and $\mathrm{v}_{2}$ the concentration of $\sum \mathrm{CO}_{2}(\mathrm{mM})$ was determined as: $\left(\mathrm{C}_{\mathrm{a}} \times\left(\mathrm{v}_{2}-\mathrm{v}_{1}\right)\right) /$ $\mathrm{v}_{0}=\sum \mathrm{CO}_{2}$, where $\mathrm{C}_{\mathrm{a}}$ is the strength of acid $(0.01 \mathrm{M})$ and $\mathrm{v}_{0}, \mathrm{v}_{1}$ and $\mathrm{v}_{2}$ are as above. The benthic consumption or production of $\mathrm{CO}_{2}$ flux was calculated by the following equation: Flux $\left(\mathrm{mmol} \mathrm{m}^{-2} \mathrm{day}^{-1}\right)=\left([\mathrm{X}]_{\mathrm{t}=1}-[\mathrm{X}]\right.$ $t=0) \times V \times 24 / A \times t$, where $X$ is the final $[X]_{t=1}$ and initial $[\mathrm{X}]_{\mathrm{t}=0}$ concentration $(\mathrm{mM})$ of $\mathrm{CO}_{2}, \mathrm{~V}$ is the volume (L) of the water column, A is the area $\left(\mathrm{m}^{2}\right)$ of the sediment surface, and $t$ is the incubation time (h). The flux is by definition an efflux, meaning that positive values indicate a net release (i.e., production) by the sediment. This flux represents net respiration rate under dark conditions.

\section{AC extraction and analyses}

All work with fragrance materials required that the staff working with them used fragrance-free detergent, shampoo and hand soap and did not use perfume (Difrancesco et al. 2004). Samples were extracted by accelerated solvent extraction (ASE 2000, Dionex, California, USA) with dichloromethane (DCM) based on a modified version of the method reported by Simonich et al. (2000). Briefly, after the sample had thawed most of the water phase was removed, the rest of the sample was mixed thoroughly, and a subsample of approximately $2 \mathrm{~g}$ ww sediment was extracted. Fifty microliter internal standard solution containing acetyl cedrene- $d 6$ $\left(1.2 \mu \mathrm{g} \mathrm{ml}^{-1}\right)$ was added to each sediment sample, mixed thoroughly into the sample and allowed to bind to the sediment for $20 \mathrm{~min}$. The water content of each sample was determined by drying a different subsample (approximately $0.5 \mathrm{~g} \mathrm{ww}$ ) at $105^{\circ} \mathrm{C}$ overnight. The sample ( $2 \mathrm{~g}$ ww sed) was mixed with $3 \mathrm{~g}$ of hydromatrix (Dionex, California, USA) to dry the sample and to create a free-flowing mixture before extraction. Hydromatrix should give the sediment a larger surface area and make room in the cell for flow of the solvents through the pores. Thirty-three-milliliter extraction cells (Dionex, California, USA) were used, with $3 \mathrm{~g}$ of silica gel (activated for $15 \mathrm{~h}$ at $105^{\circ} \mathrm{C}$ ) added at the bottom of the cell as a cleanup step. The sample-hydromatrix mixture was added. Then the remaining volume of the cell was filled with additional hydromatrix, and the content was packed tightly.

Samples were extracted twice at $60^{\circ} \mathrm{C}$ and $2000 \mathrm{psi}$ (138 bar) in static mode for $15 \mathrm{~min}$. The final volume of DCM extract was $50 \mathrm{ml}$. After the extraction, samples were dried with sodium sulfate to bind the water in the DCM as crystals. The samples, now in GC/MS vials, were frozen $\left(-20^{\circ} \mathrm{C}\right)$ until GC/MS analysis. The samples were analyzed by GC/MS using selected ion monitoring. The GC/MS used was an Agilent 6890N GC-5975 MS (Agilent technologies, California, USA) equipped with a J\&W DB-1701 capillary column $(30 \mathrm{~m}, 0.25 \mathrm{~mm}$ i.d., $0.25 \mu \mathrm{m}$ film thickness). AC was identified and quantified based on AC and AC- $d 6$ ions: one quantification ion (AC $161 \mathrm{~m} / \mathrm{z}$; AC- $d 6167 \mathrm{~m} / \mathrm{z}$ ) and two conformation ions (AC $246 \mathrm{~m} / \mathrm{z} \& 231 \mathrm{~m} / \mathrm{z}$; AC- $d 6252 \mathrm{~m} / \mathrm{z}$ \& $234 \mathrm{~m} / \mathrm{z}$ ). The ionization mode was electron impact $(70 \mathrm{eV})$, the ion source temperature was $250^{\circ} \mathrm{C}$, and the dwell time was $50 \mathrm{~ms} /$ ion. The GC temperature program used was as follows: isothermal at $35^{\circ} \mathrm{C}$ for $2 \mathrm{~min}$, $20^{\circ} \mathrm{C} \mathrm{m^{-1 }}$ to $165^{\circ} \mathrm{C}$ held for $12 \mathrm{~min}, 50^{\circ} \mathrm{C} \mathrm{min}{ }^{-1}$ to $200^{\circ} \mathrm{C}$ held for $2 \mathrm{~min}$, and finally $20^{\circ} \mathrm{C} \mathrm{m^{-1 }}$ to $280^{\circ} \mathrm{C}$ held for $5 \mathrm{~min}$. MSD ChemStation software (Agilent technologies, California, USA) was used for analysis of the chromatograms and quantification of AC.

\section{Analysis of the bacterial community (DNA extraction and PCR)}

DNA from the four treatments was extracted from sediment samples (six replicates) on day 16 of the experiment (0.5 g ww sediment used for DNA isolation). The DNA was extracted with FastDNA ${ }^{\circledR}$ SPIN Kit for soil (Qbiogene, Irvine, CA, USA) according to the manufacturer's instructions. PCR was performed using puRe Taq Ready-to-Go PCR beads (Amersham Biosciences, Uppsala, Sweden) containing dNTP, buffer and polymerase. To these tubes were added $1 \mu \mathrm{l}$ of $10 \times$ diluted DNA, $1 \mu 120 \mu \mathrm{M}$ 27F FAM forward primer (AGAGTTTGATCMTGGCTCAG; Weinbauer et al. 2002), $1 \mu \mathrm{l} 20 \mu \mathrm{M}$ 907R reverse primer (CCGTCAATTCMT TTRAGTTT; 
slightly modified from Weinbauer et al. 2002), and $22 \mu 1$ sterile-filtered MilliQ water. Samples were incubated in a DNA Engine DYAD ${ }^{\mathrm{TM}}$ - Peltier Thermal Cycler (MJ Research, GMI, Minnesota, USA) using the following program: incubating at $94^{\circ} \mathrm{C}$ for 2 min (denaturing DNA), then amplification for 32 cycles consisting of denaturing for $20 \mathrm{~s}$ at $94^{\circ} \mathrm{C}$, annealing for $40 \mathrm{~s}$ at $56^{\circ} \mathrm{C}$ and extension for $50 \mathrm{~s}$ at $72^{\circ} \mathrm{C}$, after this a final step of extension for 6 min at $72^{\circ} \mathrm{C}$.

\section{T-RFLP}

The pure DNA was treated with the restriction enzyme AluI (New England BioLabs, Beverly, MA, USA). Restriction digests were done in a GeneAmp PCR system 9600 (Perkin Elmer, Beaconsfield, England) for $12 \mathrm{~h}$ at $37^{\circ} \mathrm{C}$ followed by $20 \mathrm{~min}$ at $65^{\circ} \mathrm{C}$ where the enzyme was denatured. The samples were Sephadex purified and MegaBace ET90-R size standard (GE Healthcare, Little Chalfont, UK) was added to the samples as an internal size standard. The samples were heat denatured before injection into an ABI 3130 (Applied Biosystems, Foster City, CA, USA) automatic sequencer and run at $15000 \mathrm{~V}$.

\section{Analysis of the T-RFLP profiles}

Electropherograms were analyzed using the software Bionumerics Version 5.00 (Applied Maths, Sint-Martens-Latem, Belgium). The program assigned bands on the gel pictures to each of the peaks in the electropherograms, and these were all examined manually to check that only true peaks were included. The bands in the different lanes of the gel picture were compared and peak height quantified. The data were then exported to Microsoft Excel. The diversities of the bacterial communities were calculated from the number of peaks and their relative abundance $(p)$ as "species" richness (S), Shannon diversity index $\left(\mathrm{H}^{\prime}\right)$ and evenness $\left(\mathrm{J}^{\prime}\right)$. Where $\mathrm{H}^{\prime}=-\sum\left(p_{i} \times \ln \left(p_{i}\right)\right)$ and $\mathrm{J}^{\prime}=\mathrm{H}^{\prime} / \ln (\mathrm{S})($ Magurran 2004).

\section{Statistical analysis}

All statistical analyses of worm survival, $\mathrm{CO}_{2}$ flux, TOM and AC concentrations were performed using SYSTAT (vers. 11, Systat software, San Jose, CA, USA). A result is defined as statistically significant when $p \leq 0.05$ and as marginally significant when $0.05<p \leq 0.1$. Data are presented as mean \pm 1 standard deviation unless stated otherwise.

A two-sample $t$-test was used to test for differences in TOM content in the sediment at experimental start (i.e., day 0 ), for significant effects of AC exposure (with and without AC) on worm survival, and of worm presence (i.e., with versus without worms) for the final AC concentration in the sediment.

A two-way ANOVA was used to test for interaction effects of AC exposure and worm presence on both $\mathrm{CO}_{2}$ flux and TOM at experimental termination. Two-way ANOVA was also used to test for interaction effects of worm presence and exposure time on final AC concentration. If no interaction was found then the analysis was rerun without the interaction (see below).

Three-way ANOVA was used to test for interaction effects among AC exposure, worm presence and experimental time on $\mathrm{CO}_{2}$ flux. In cases with no significant interaction a reduced model was run (i.e., without the three-way interaction term). If one or more of the twoway interactions were not significant, the one with the least significant $p$-value was omitted and a reduced model (without this specific interaction term) was run. This process was repeated until the simplest model with significant $p$-values was obtained.

Statistical analysis of the T-RFLP profiles was performed using Primer 5 software (Primer E, Plymouth, UK). The data were standardized for each sample by dividing the height of every peak by the summarized height of all the peaks in the sample, i.e., the peak heights were standardized to percentage of the total peak height (Wolsing and Priemé 2004). For every pair of samples Bray-Curtis dissimilarity coefficients were calculated (Clark and Warwick 2001). The matrix now created was used for multidimensional scaling (MDS) plots and statistical analysis of similarity. The MDS plots were created by rank ordering the Bray-Curtis matrix. MDS aims to construct a sample map whose inter-point distances have the same rank order as the corresponding Bray-Curtis similarity matrix (Wolsing and Priemé 2004). To test for the effects of the different treatments on bacterial community structure, the ANOSIM function in Primer 5 was used. The ANOSIM function is an analysis of similarity based on the rank order of the Bray-Curtis matrix. A two-way crossed function was chosen to test between the four treatments for an effect of AC treatment and worm treatment on bacterial community structure. The diversity, richness and evenness were tested for treatment effects (with/without worms, with/without AC) in SYSTAT using a twoway ANOVA, including the interaction term. If no interaction was found, then the test was run again without the interaction (see above).

\section{Results}

\section{AC concentration}

At experimental start (i.e., day 0), the actual AC con-

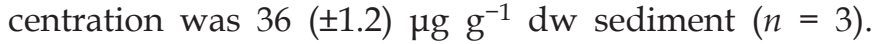




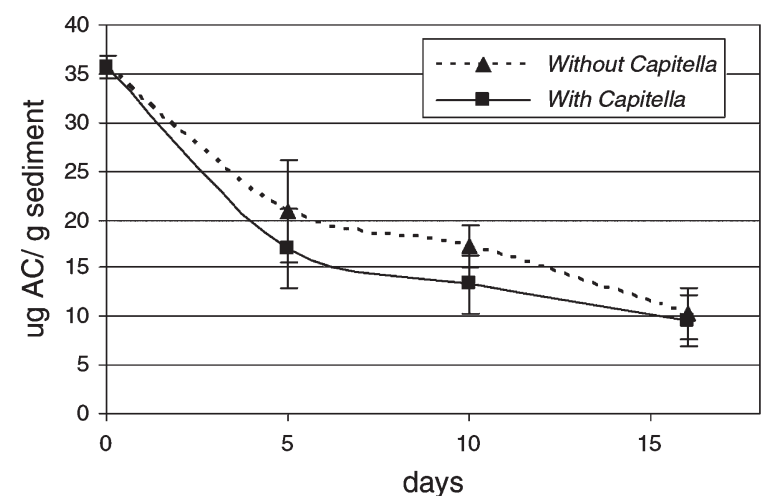

Figure 1. The AC concentration ( $\mu \mathrm{g} \mathrm{AC}^{-1} \mathrm{dw}$ sediment) for the two treatments: with and without Capitella. The initial concentration (day 0) represents the sediment just after it had been spiked (no worms yet added). Data are presented as mean $\pm S D$.

Time of exposure and worm treatment (i.e., with-/without worms) interacted to affect the concentration of AC in the sediment (two-way ANOVA: $\mathrm{F}=2.536$; $\mathrm{df}=6$; $p=0.041$ ) (Figure 1). The amount of AC on day 5 suggests that the initial loss of $\mathrm{AC}$ from the sediment was fastest in the treatment with Capitella. In both treatments with and without Capitella the initial loss of AC from the sediment (days 0-5) was faster than the rate of loss from day 5 to 16 (Figure 1). The Capitella treatment had a lower AC concentration on day 5 and 10, but at experimental termination (day 16) no significant difference in AC concentration was found between treatments with and without worms ( $t$-test: $\mathrm{t}=0.239 ; \mathrm{df}=12 ; p=0.815)$. The final mean AC concentration in the sediment was 10 $( \pm 2.7) \mu \mathrm{g} \mathrm{g}^{-1} \mathrm{dw}$ sediment and $10( \pm 2.6) \mu \mathrm{g} \mathrm{g}^{-1} \mathrm{dw}$ sediment in treatments with and without worms, respectively, which equals $28 \%$ of the initial concentration remaining in the sediment. No AC was detected in the control sediment.

\section{Survival of C. teleta}

From the initial number of seven live worms per vial, worm survival declined with time, especially in the ACtreated sediments (Figure 2). Worm survival was significantly $(p=0.021)$ reduced in AC treatments $(57 \pm 22.1 \%$, $n=6)$ compared to treatments without AC $(88 \pm 16.7 \%$, $n=6)$ at experimental termination (i.e., day 16).

\section{$\mathrm{CO}_{2}$ flux}

The data from day 5 were omitted from the calculations, because the shaking-table had stopped some time during the night. It is judged that this had an impact on the results, which were much lower than the results from the other sampling times (data not shown). The lower

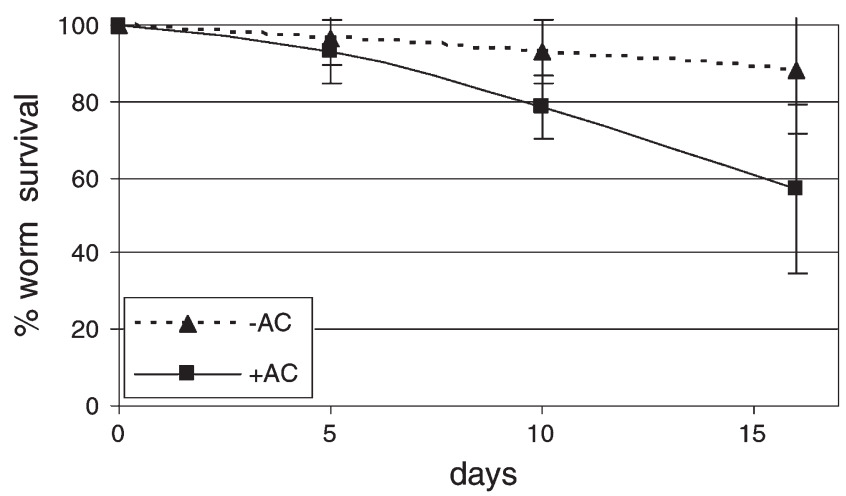

Figure 2. Percent $C$. teleta survival in treatments with (+AC) and without $(-\mathrm{AC})$ acetyl cedrene. Worms were added to the sediments on day 0 , and harvested on days 5, 10 and 16. Data are presented as mean $\pm \mathrm{SD}$.

$\mathrm{CO}_{2}$ fluxes for the day 5 samples suggest that the sediment had become anaerobic.

There was no significant interaction between exposure time, worm treatment and AC treatment (threeway ANOVA: $\mathrm{F}=0.735 ; \mathrm{df}=1 ; p=0.398)$. Likewise, there was no significant interaction between $\mathrm{AC}$ and worm treatment (two-way ANOVA: $\mathrm{F}=0.162 ; \mathrm{df}=1$; $p=0.690$ ) or between time and AC treatment (twoway ANOVA: $\mathrm{F}=0.792 ; \mathrm{df}=1 ; p=0.380$ ). The reduced model showed that AC had no significant effect on the $\mathrm{CO}_{2}$ flux in the system (Table 1). However, $\mathrm{CO}_{2}$ flux was greater in treatments without worms than in treatments with worms on day 16 of the experiment (Figure 3). Furthermore there was a significant interaction between worm treatment and time (two-way ANOVA: $\mathrm{F}=6.101$; $\mathrm{df}=1 ; p=0.019)$. For both treatments without worms (with/without $\mathrm{AC}$ ) $\mathrm{CO}_{2}$ flux increased from day 10 to 16, whereas for treatments with worms $\mathrm{CO}_{2}$ flux decreased slightly from day 10 to 16 (Figure 3).

\section{TOM content}

The content of TOM was equal for sediments with and without AC at experimental start ( $t$-test: $p=0.989)$. There was no interaction between AC- and worm treatments for TOM at experimental termination (two-way ANOVA: $\mathrm{F}=0.160 ; \mathrm{df}=1 ; p=0.692$ ). However, TOM was significantly reduced in treatments with worms at

Table 1. ANOVA results for the main effects on $\mathrm{CO}_{2}$ flux

\begin{tabular}{llcl}
\hline & \multicolumn{2}{l}{$\mathrm{CO}_{2}$ flux } & \\
\cline { 2 - 4 } & \multicolumn{1}{l}{$\mathrm{F}$} & $\mathrm{df}$ & $p$ \\
\hline AC treatment & 1.223 & 1 & 0.278 \\
Worm treatment & 5.739 & 1 & 0.023 \\
Time & 10.089 & 1 & 0.003 \\
\hline
\end{tabular}


Figure 3. $\mathrm{CO}_{2}$ flux

$\left(\mathrm{mmol} \mathrm{m}^{-2}\right.$ day $\left.^{-1}\right)$ in the wa-

ter phase above the sediment

for the four treatments used in the experiment. The measurements were made on day 10 and 16 of the experiment. Data are presented as mean \pm SD.
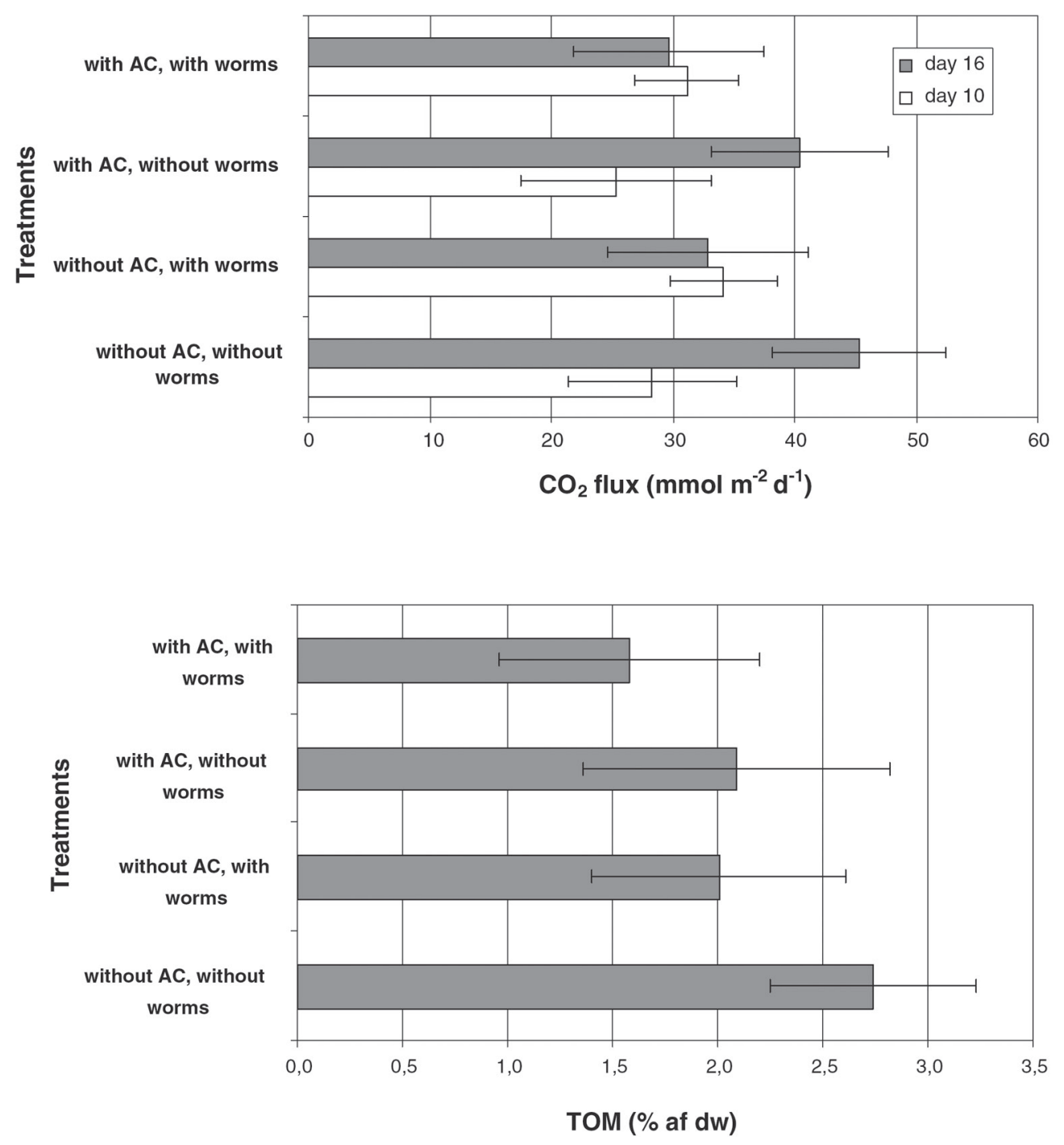

Figure 4. TOM content in the sediment at experimental termination (i.e., day 16) for each treatment. Data are presented as mean $\pm \mathrm{SD}$. experimental termination compared to in treatments without worms (ANOVA: $\mathrm{F}=5.039 ; \mathrm{df}=1 ; p=0.032$; Figure 4). Furthermore, AC appeared to reduce TOM content in the sediment compared to treatments without $\mathrm{AC}$, but the difference was only marginally significant (ANOVA: $\mathrm{F}=3.772 ; \mathrm{df}=1 ; p=0.061$; Figure 4 ).

\section{Structure and diversity of the bacterial community}

The similarity between the T-RFLP profiles was visualized using MDS plots (Figure 5). Samples from the different treatments did not differ much from each other on the basis of the Bray-Curtis similarity, and many of the samples in the MDS plot were clustered together. Two of the treatments seemed, however, to be a little further apart than the others (for some of the samples). This is the control treatment (i.e., without AC without worms) which tended to be located in the lower right side corner and the treatment with worms and with AC, which tended to have some of its samples far to the left side. Digital comparisons between T-RFLP band patterns showed that band number and position varied, and it was observed that a number of bands had disappeared in the treatment with worms and with AC. The results of the ANOSIM test showed, however, that there was no effect of AC on the structure of the sediment bacterial community $(p=0.476)$, and that the effect of worm treatment on bacterial community structure was marginally significant $(p=0.089)$.

The richness and evenness in all treatments were high (Table 2), but there were no significant differences or interactions for richness, Shannon diversity index or evenness between treatments (with/without AC, with/ without worms) $(p>0.05)$. 


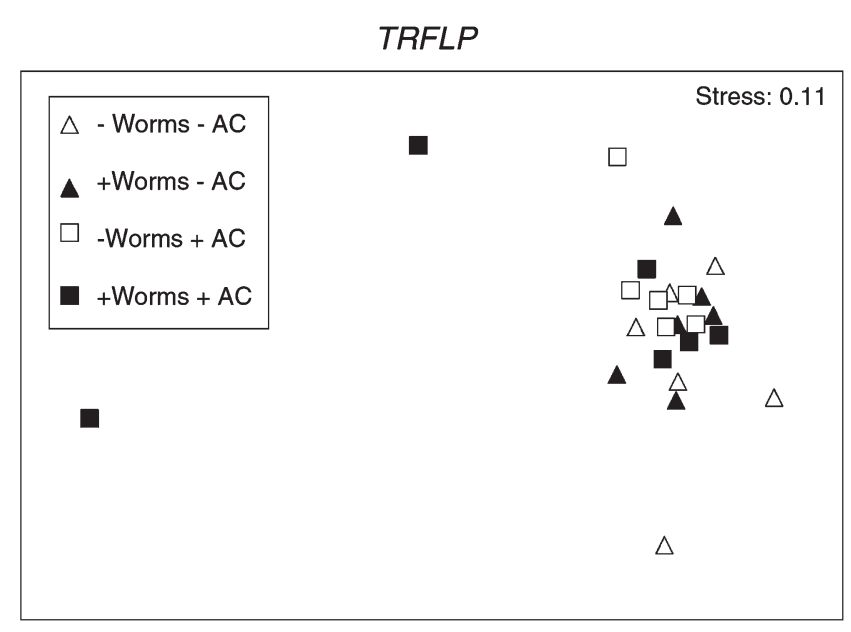

Figure 5. MDS plot of the T-RFLP patterns from the four treatments based on Bray-Curtis similarities in gene fragments digested with Alu1 enzyme. Treatments: without worms, without AC (-worms; -AC); with worms, without AC (+worms; $-\mathrm{AC})$; without worms, with $\mathrm{AC}$ (-worms; +AC), and with worms and AC (+worms; +AC).

Table 2. Diversities of the bacterial communities calculated from data from T-RFLP analysis of number of peaks and their relative abundance $(p)$ as "species" richness $(S)$, Shannon diversity index $\left(\mathrm{H}^{\prime}\right)$ and evenness $\left(\mathrm{J}^{\prime}\right)$

\begin{tabular}{llll}
\hline Treatment & $\mathrm{S}$ & $\mathrm{H}^{\prime}$ & $\mathrm{J}$ \\
\hline With AC, with worms & $54( \pm 14.9)$ & $3.7( \pm 0.27)$ & $0.94( \pm 0.019)$ \\
With AC, without worms & $63( \pm 5.2)$ & $3.9( \pm 0.05)$ & $0.93( \pm 0.013)$ \\
Without AC, with worms & $63( \pm 6.0)$ & $3.8( \pm 0.09)$ & $0.93( \pm 0.011)$ \\
Without AC, without worms & $66( \pm 10.1)$ & $3.9( \pm 0.13)$ & $0.92( \pm 0.004)$ \\
\hline
\end{tabular}

Data are presented as mean $\pm \mathrm{SD}$

\section{Discussion}

\section{AC concentration}

The actual AC concentration in the sediment at experimental start was $72 \%$ of the spiked concentration (i.e., $50 \mu \mathrm{g} \mathrm{AC} \mathrm{g}^{-1} \mathrm{dw}$ sed), which is within the range of what has been found in related studies in our laboratory (unpublished data). A substantial loss of AC from the sediment occured during the course of the experiment regardless of worm presence (Figure 1), which suggests that abiotic and/or microbial processes contributed to AC degradation. However, at the end of the experiment $10 \mu \mathrm{g} \mathrm{AC} \mathrm{g}^{-1} \mathrm{dw}$ sediment was still present both in systems with and without worms. Artola-Garicona et al. (2003a) found that microbial degradation was the rate-limiting step in the biodegradation of the two fragrance materials HHCB and AHTN in sewage sludge during the first $60 \mathrm{~h}$ of degradation. HHCB and AHTN have $\log \mathrm{K}_{\mathrm{ow}}$ values of about 5.7 (Artola-Garicona et al. $2003 \mathrm{~b}$ ), which is in the same range as $\log \mathrm{K}_{\mathrm{ow}}$ of 5.6-5.9 (Simonich et al. 2000) for AC. So the compounds HHCB and AHTN may be expected to similarly sorb to particles as AC, though the different materials (i.e., sediment or sewage sludge) will also affect the sorption, and due to the different structure of these chemicals their fate in the presence of organic matter may also be influenced by other factors than their $\mathrm{K}_{\mathrm{ow}}$. However, the present study continues far beyond the $60 \mathrm{~h}$ described by Artola-Garicona et al. (2003a). The loss of AC from the sediment slowed down considerably (i.e., day 5 to 16 ) in the present study possibly because it became less available, due to sorption onto particles in the sediment and/or it became trapped in micropores. Sorption is generally said to become stronger the longer sediments are in contact with the contaminants (Bosma et al. 1997).

The significant interaction between time and worm treatment indicates that worm activity enhanced the initial loss of AC from sediment. Worm bioturbation, which consists of both particle reworking and exchange of sediment pore water with overlying water by respiratory pumping (Yingst and Rhoads 1980), may lead to an increased flushing of compounds out of the sediment. It is therefore likely that $\mathrm{AC}$ will be more rapidly removed from sediments inhabited by bioturbating infauna. Bioturbation also leads to transport of oxygenated water from the water phase to the sediment (Fry 1982; Yingst and Rhoads 1980). Bauer and Capone (1985) showed that aerobic sediments have a higher degradation rate of PAH than anaerobic sediments. It has also been shown that PAH degradation in marine sediments is enhanced by stimulation of microbial activity in the presence of Capitella (Bauer et al. 1988; Gardner et al. 1979). On the other hand, Madsen et al. (1997) found that the presence of Capitella increased the downward transport of the PAH, fluoranthene in surface sediment. However, a downward transport of AC is not likely due to the low sediment depth of maximum $1 \mathrm{~cm}$ in the present study.

Bioaccumulation of AC in the worms could also contribute to a faster removal of AC from the sediment, especially since living worms were removed from the sediment prior to the extraction of AC. Borgers (2003b) showed that the bioconcentration factor (BCF) for $\mathrm{AC}$ is considerable for fish (Oncorhynchus mykiss), with BCF found to be between 867 and 3920 for the edible part and intestines, respectively. It is therefore likely that other animals will also accumulate AC in their tissues. For future studies a measurement of the AC concentration in the worms would be a way to clarify the degree to which AC accumulates in Capitella tissue.

The AC concentration at experimental termination (i.e., day 16) was not significantly different for the treatments with and without worms (Figure 1), which is in contrast to other studies showing that AC disappearance from the sediment is significantly increased in 
the presence of Capitella compared to systems without worms (Dai 2009). Dai (2009) found that $12.3-30.7 \%$ of the added AC disappeared in systems without worms and that $94-99.6 \%$ was lost in systems with Capitella regardless of organic content in the sediment. However, there are several differences between the present study and the study by Dai (2009), the most important being the difference in the sediment handling. In contrast to the study by Dai (2009) the sediment in the present study was a mixture of fresh (e.g., non-frozen) and frozen sediment which provided a source of active microbes from the very start of the exposure to AC, possibly leading to a greater role of microbial degradation in the present study compared to Dai (2009).

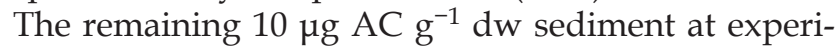
mental termination can be an indication that the remaining $\mathrm{AC}$ was very strongly bound to the sediment and therefore not available for worms or microbes.

\section{Survival of C. teleta}

The number of worms that survived in the AC contaminated sediment was significantly reduced compared to the sediment without AC (Figure 2). The AC concentration used in the present study $\left(50 \mu \mathrm{g} \mathrm{g}^{-1} \mathrm{dw}\right.$ sediment), resulting in substantial mortality of $C$. teleta, is presumably higher than concentrations that can be expected in the field. Simonich et al. $(2000,2002)$ measured the concentrations of AC in wastewater influent and effluent to be in the range of 2610-8110 and $76-1,359 \mathrm{ng} \mathrm{l}^{-1}$, respectively. According to Salvito et al. (2002) the predicted environmental concentration, PEC, for fragrance materials can be calculated from the effluent concentration divided by a threefold dilution factor: $\mathrm{PEC}=2^{\circ}$ eff. conc./3. With an average effluent of $717.5 \mathrm{ng} \mathrm{AC} 1^{-1}$ this gives a $\mathrm{PEC}_{\text {water }}$ of $2.39 \times 10^{-4} \mu \mathrm{g} \mathrm{l^{-1 }}$. Using an equilibrium partitioning approach as indicated in the "Technical Guidance Document on risk assessment" (European Commission 2003) a PEC $_{\text {sediment }}$ of $1.25 \mu \mathrm{g} \mathrm{AC} \mathrm{g}{ }^{-1}$ is estimated. This is a very rough estimate based on the assumption that the only route for $\mathrm{AC}$ to the environment is through sewage treatment plants, though other routes are possible (Salvito et al. 2002), such as agricultural spreading of sewage sludge. Difrancesco et al. (2004) reported AC concentrations of $9.0 \pm 1.6 \mu \mathrm{g} \mathrm{g}^{-1} \mathrm{dw}$ sludge and $31.3 \pm 5.1 \mu \mathrm{g} \mathrm{g}^{-1} \mathrm{dw}$ sludge in two wastewater treatment plants. However, when this sludge is amended to soil the environmental concentration will drop many fold below these concentrations (Difrancesco et al. 2004).

Unfortunately studies on AC concentration in sediments have to our knowledge not been published, and the actual concentration that Capitella is likely to be exposed to in the field is therefore uncertain.

\section{$\mathrm{CO}_{2}$ flux}

The $\mathrm{CO}_{2}$ flux in the systems did not seem to be affected by AC treatment. These results are consistent with those of Holmer et al. (1997), who found that sediment $\mathrm{CO}_{2}$ fluxes were not significantly affected by the $\mathrm{PAH}$, flouranthene. Thus, a possible explanation is that $\mathrm{CO}_{2}$ flux has low sensitivity towards toxic compounds (Van Beelen and Doelman 1997), because it is a process that can be carried out by many different microorganisms. The effect of worms on the $\mathrm{CO}_{2}$ flux is complex. On day 10 the $\mathrm{CO}_{2}$ fluxes were higher for the worm-treated samples, and on day 16 the $\mathrm{CO}_{2}$ fluxes were higher for the treatments without worms (Figure 3). Bauer et al. (1988) and Holmer et al. (1997) studied the effects of PAHs and the impact of Capitella on microbial activity in sediment. They found that the presence of Capitella increased the respiration in the sediment both with and without PAH. Respiration in these studies was measured while the worms were still in the sediment, therefore it is not surprising that respiration was higher in the presence of worms, since the worms would also be respiring. In the present study, however, the worms were removed from the sediment before measuring the $\mathrm{CO}_{2}$ flux, and consequently it was only the microbial respiration that was measured.

Different factors can affect microbial activity in sediments in the presence or absence of macrofauna. Infauna may increase the oxygen level in sediment due to their digging and feeding activity (Fry 1982), and thereby increase aerobic microbial activity and production. Furthermore Alongi (1985) found that bacterial productivity was significantly higher in sediment tubes made by Capitella than in the sediment around them. This is evidence for a higher microbial activity in sediments inhabited by Capitella, but other interactions between microorganisms and Capitella could inhibit microbial activity, such as grazing by worms on the microorganisms and competition between worms and microbes for organic matter (Fry 1982; Lopez and Levinton 1987).

Kemp (1987) found that polychaetes consume less than $10 \%$ of the benthic bacterial production. Grazing of this intensity might actually result in a positive stimulation of both bacterial production and growth (Fry 1982; Yingst and Rhoads 1980). However, if grazing pressure is combined with competition for organic matter then the grazing could in fact have caused the microbial activity to decline. The TOM results showed that there was less TOM in the worm-treated samples at experimental termination compared to the sediments without worms, and since sediments are generally considered to be nutrient poor (Lopez and Levinton 1987), it is possible that the competition for organic matter together with grazing inhibited microbial activity on day 16 . 


\section{TOM}

The TOM content in the sediment was significantly reduced by the worm treatment. Although Capitella plays an important role in the turnover of sediment organic matter (Méndez et al. 2001), the amount of sediment provided to worms was in excess of what they could have consumed. Méndez et al. (2001) found that one Capitella on average processed $5.3 \mathrm{mg} \mathrm{dw}$ of sediment per day under similar laboratory conditions, except with $6.62 \pm 1.30 \%$ organic matter in the sediment. Thus, approximately $594 \mathrm{mg} \mathrm{dw}$ sediment would have been processed in the course of the present experiment (i.e., 16 days with seven worms). The total amount of sediment in each beaker was $13 \mathrm{~g} \mathrm{dw}$ (i.e., $23.3 \mathrm{~g} \mathrm{ww}$ ), so only a small fraction of the total amount of sediment would have been processed by Capitella. The difference might therefore be due to the stimulation of microbial degradation of organic matter by Capitella.

\section{Bacterial diversity and community structure}

The bacterial community structure in the sediment was not significantly changed by exposure to AC or the presence of worms. The most obvious explanation is therefore that $\mathrm{AC}$ at the applied concentration was not toxic to the bacterial community under the conditions of this study. Bacterial diversity would be expected to decrease after the addition of toxicants, because the most sensitive species would be eliminated from the community (Shugart and Theodorakis 1996). However, no change in the diversity of the bacterial community exposed to AC in the sediments was found in this study. This is consistent with the findings of Petersen et al. (2004), who found no changes in diversity of bacterial communities in the sediment exposed to biocides, when examined for total extracted DNA using PCR-DGGE. They ascribed this result to the persistence of extracellular DNA from dead cells in the sediment. It has been reported that DNA can be persistent in the environment for weeks or even months after its release from dead cells (Romanowski et al. 1993). Petersen et al. (2004) further argued that the persistence of extracellular DNA can therefore hide effects of toxic compounds on the diversity of bacteria, because this DNA is amplified during PCR together with the DNA extracted from surviving bacteria. This might also explain our results. Examining the active part of the community by extracting rRNA from the sediment would have provided information on effects on living bacteria. However, it was not possible to make this method work for sediment.

As for the richness of the communities 54-66 (Table 2) different TRFs (terminal restriction fragments) were found demonstrating highly diverse communities (Grant et al. 2007; Liu et al. 1997). Grant et al. (2007) found 49 different TRFs in PAH contaminated soil, but the number of TRFs will depend on the restriction enzyme used (Dunbar et al. 2000; Liu et al. 1997). Also the analysis of the electropherograms can be a source of uncertainty between studies. It is therefore difficult to compare the TRF richness of different studies if they are not done in exactly the same way. In addition to the high richness of the bacterial communities a high evenness was found ( $\mathrm{J}^{\prime}>0.9$; Table 2). Evenness is simply a measure of how similar the species (i.e., ribotypes) are in their abundance (Magurran 2004). A community in which most species are equally abundant is one that has high evenness (Magurran 2004). The high evenness of the communities therefore suggests that dominant organisms were not favoured in the sediments due to AC exposure. This is consistent with Grant et al. (2007) who found no dominant ribotypes when examining the bacterial community in PAH contaminated soil using TRFLP analysis.

The high richness and evenness of the bacterial community are indications of a stable community. Stable communities are more resistant and resilient to changes in their environment (Loreau 2000; Naeem and Li 1997). However, most natural systems will be subjected to several kinds of stress at a time due to natural fluctuations and human activities, and it has been shown that additional stress can decrease the resistance and resilience of microbial communities (Griffiths et al. 2000; ToborKaplon et al. 2005, 2006). In the present study changes in the communities were most profound for the sediment subjected to two disturbing factors (i.e., with worms with AC) compared to the control (i.e., without worms without $\mathrm{AC}$ ), though this was not statistically significant.

\section{Conclusion}

The present study has contributed to the examination of fate and effects of one of the many fragrance materials released into the environment. The results suggest that AC may accumulate in sediments, as $28 \%$ of the amount added was not removed after 16 days. The results showed that $\mathrm{AC}$ concentrations declined over time and declined faster in the presence of worms, though the final concentrations with/without worms were similar. Whereas the overall decline could be due to degradation (biotic or abiotic), the additional worm effect was likely due to flushing of labile AC to overlying water and uptake by worms. In addition we showed that $C$. teleta was more sensitive to AC exposure than microbial respiration, and that bacterial community structure, richness, diversity and evenness were insensitive to $A C$ under the conditions applied in the present study. More reliable methods for estimating living bacterial diversity in sediments (i.e., rRNA) might reveal additional changes that were not detectable with the methods used here. 
The environmental concentration of $\mathrm{AC}$, as noted earlier, is anticipated to be much lower than the $50 \mu \mathrm{g} \mathrm{AC} \mathrm{g}{ }^{-1} \mathrm{dw}$ sed used as the test concentration in this study. Based on the conditions of this study, there would appear to be no evident risk to sediment microorganisms. A more robust study, with Capitella over a wider range of concentrations, would provide insight into the feasibility of this method to be used more broadly in sediment risk assessment and may establish a more accurate NOEC for AC. Furthermore, as noted by the studies for HHCB and AHTN, albeit structurally unrelated fragrance materials, there are multiple factors to consider regarding the environmental behavior of AC some of which may be elucidated with more robust sediment studies.

Acknowledgments - The authors thank K. Vestberg for assistance with the molecular work and P. Christensen for assistance with the fragrance extraction method. Our thanks also go to G. Banta and A.B. Faarborg for guidance on the $\mathrm{CO}_{2}$ measurement. Lastly, we are grateful to L.D. Rasmussen, National Veterinary Institute, DTU for running the T-RFLP analysis. This work was partly funded by a grant from the Research Institute for Fragrance Materials.

\section{References}

Alongi DM (1985) Microbes, meiofauna, and bacterial productivity on the tubes constructed by the polychaete Capitella capitata. Mar Ecol Prog Ser 23:207-208

Artola-Garicano E, Borkent I, Damen K, Jager T, Vaes WHJ (2003a) Sorption kinetics and microbial degradation activity of hydrophobic chemicals in sewage sludge: Model and measurements based on free concentrations. Environ Sci Technol 37:116-122

Artola-Garicano E, Borkent I, Hermens JLM, Vaes WHJ (2003b) Removal of two polycyclic musks in sewage treatment plants: Freely dissolved and total concentrations. Environ Sci Technol 37:3111-3116

Aschmann SM, Arey J, Atkinson R, Simonich SL (2001) Atmospheric lifetimes and fates of selected fragrance materials and volatile model compounds. Environ Sci Technol 35:3595-3600

Bååth E, Díaz-Raviña M, Frostegård Å, Campbell CD (1998) Effect of metal-rich sludge amendments on the soil microbial community. Appl Environ Microbiol 64:238-245

Bauer JE, Capone DG (1985) Effects of four aromatic organic pollutants on microbial glucose metabolism and thymidine incorporation in marine sediment. Appl Environ Microbiol 49:828-835

Bauer JE, Kerr RP, Bautista MF, Decker CJ, Capone DG (1988) Stimulation of microbial activities and polycyclic aromatic hydrocarbon degradation in marine sediments inhabited by Capitella capitata. Mar Environ Res 25:63-84

Bickers DR, Calow P, Greim HA, Hanifin JM, Rogers AE, Saurat J-H, Sipes IG, Smith RL, Tagami H (2003) The safety assessment of fragrance materials. Regul Toxicol Pharmacol $37: 218-273$
Blake JA, Grassle JP, Eckelbarger KJ (2009) Capitella teleta, a new species designation for the opportunistic and experimental Capitella sp. I, with a review of the literature for confirmed records. Zoosymposia 2:25-53

Borgers DM (2001a) Fresh water algal growth inhibition test with methyl cedryl ketone- ${ }^{14} \mathrm{C}$ (water accommodated fractions). NOTOX project 277201. NOTOX substances $94302 \&$ 99225. RIFM report

Borgers DM (2001b) Acute toxicity study in Daphnia magna with methyl cedryl ketone- ${ }^{14} \mathrm{C}$ (water accommodated fractions). NOTOX project 277212. NOTOX substances $94302 \&$ 99225. RIFM report

Borgers DM (2001c) 96-hour acute toxicity study in fathead minnow with methyl cedryl ketone- ${ }^{14} \mathrm{C}$ (water accommodated fractions). NOTOX project 277223. NOTOX substances 94302 \& 99225. RIFM report

Borgers DM (2003a) Daphnia magna, reproduction test with methyl cedryl ketone $\left(-{ }^{14} \mathrm{C}\right)$ (flow-through). NOTOX project 277245. NOTOX substances $94302 \& 99225$. RIFM report

Borgers DM (2003b) Fish bioconcentration test in rainbow trout with methyl cedryl ketone $\left({ }^{14} \mathrm{C}\right)$ (flow-through). NOTOX project 337455. NOTOX substances $94302 \& 99225$. RIFM report

Bosma TNP, Middeldorp PJM, Schraa G, Zehnder AJB (1997) Mass transfer limitation of biotransformation: Quantifying bioavailability. Environ Sci Technol 31:248-252

Capone DG, Reese DD, Kiene RP (1983) Effects of metals on methanogenesis, sulfate reduction, carbon dioxide evolution, and microbial biomass in anoxic salt marsh sediments. Appl Environ Microbiol 45:1586-1591

Clark KR, Warwick RM (2001) Change in marine communities: An approach to statistical analysis and interpretation. Primer-E, Plymouth

Dai L (2009) Fate and effects of sediment-associated acetyl cedrene in sediments inhabited by the deposit feeder, Capitella sp. I. Master thesis, Roskilde University. Roskilde

Difrancesco AM, Chiu PC, Standley LJ, Allen HE, Salvito DT (2004) Dissipation of fragrance materials in sludgeamended soils. Environ Sci Technol 38:194-201

Draisci R, Marchiafava C, Ferretti E, Palleschi L, Catellani G, Anastasio A (1998) Evaluation of musk contamination of freshwater fish in Italy by accelerated solvent extraction and gas chromatography with mass spectrometric detection. J Chromatogr A 814:187-197

Duedahl-Olesen L, Cederberg T, Pedersen KH, Højgård A (2005) Synthetic musk fragrances in trout from Danish fish farms and human milk. Chemosphere 61:422-431

Dunbar J, Ticknor LO, Kuske CR (2000) Assessment of microbial diversity in four southwestern United States soils by $16 \mathrm{~S}$ rRNA gene terminal restriction fragment analysis. Appl Environ Microbiol 66:2943-2950

European Commission (2003) Technical guidance document on risk assessment. Part II \& III. European chemicals bureau. European Commission; accessed January 10, 2008 at http://ecb.jrc.it/tgd/

Franke S, Meyer C, Heinzel N, Gatermann R, Hühnerfuss H, Rimkus G, König WA, Francke W (1999) Enantiomeric 
composition of the polycyclic musks HHCB and AHTN in different aquatic species. Chirality 11:795-801

Fromme H, Otto T, Pilz K, Neugebauer F (1999) Levels of synthetic musks; Bromocyclene and PCBs in eel (anguilla anguilla) and PCBs in sediment samples from some waters of Berline/Germany. Chemosphere 39:1723-1735

Fromme H, Otto T, Pilz K (2001) Polycyclic musk fragrances in fish samples from Berlin waterways, Germany. Food Addit Contam 18:937-944

Frostegård A, Tunlid A, Bååth E (1993) Phospholipid fatty acid composition, biomass, and activity of microbial communities from two soil types experimentally exposed to different heavy metal. Appl Environ Microbiol 59:3605-3617

Fry JC (1982) Interactions between bacteria and benthic invertebrates. In: Nedwell DB, Brown CM (eds.) Sediment microbiology. Academic Press, London, pp 171-201

Gardner WS, Lee RF, Tenore KR, Smith LW (1979) Degradation of selected polycyclic aromatic hydrocarbons in coastal sediments: Importance of microbes and polychaete worms. Water Air Soil Pollut 11:339-347

Gatermann R, Hellou J, Hühnerfuss H, Rimkus G, Zitko V (1999) Polycyclic and nitromusks in the environment: A comparison between Canadian and European aquatic biota. Chemosphere 38:3431-3441

Gatermann R, Biselli S, Hühnerfuss H, Rimkus GG, Hecker M, Karbe L (2002a) Synthetic musks in the environment. Part 1: Species-dependent bioaccumulation of polycyclic and nitro musk fragrances in freshwater fish and mussels. Arch Environ Contam Toxicol 42:437-446

Gatermann R, Biselli S, Hühnerfuss H, Rimkus GG, Franke S, Hecker M, Kallenbon R, Karbe L, König WA (2002b) Synthetic musks in the environment. Part 2: Enantioselective transformation of the polycyclic musk fragrances $\mathrm{HHCB}$, ANTN, AHDI, and ATII in freshwater fish. Arch Environ Contam Toxicol 42:447-453

Grant RJ, Muckian LM, Clipson NJW, Doyle EM (2007) Microbial community changes during the bioremediation of creosote-contaminated soil. Lett Appl Microbiol 44:293-300

Grassel JP, Grassel JF (1976) Sibling species in the marine pollution indicator Capitella (polychaeta). Science 192:567-569

Grassle J (1980) Polychaete sibling species. In: Brinkhurst RO, Cook DG (eds.) Aquatic oligochaete biology. Plenum Press, New York, pp 25-32

Griffiths BS, Ritz K, Bardgett RD, Cook R, Christensen S, Ekelund $\mathrm{F}$, Sørensen SJ, Bååth E, Bloem J, de Ruiter PC, Dolfing J, Nicolardot B (2000) Ecosystem response of pasture soil communities to fumigation-induced microbial diversity reductions: An examination of the biodiversity-ecosystem function relationship. Oikos 90:279-294

Holmer M, Forbes VE, Forbes TL (1997) Impact of the polychaete Capitella sp. 1 on microbial activity in an organicrich marine sediment contaminated with the polycyclic aromatic hydrocarbon fluoranthene. Mar Biol 128:679-688

Kannan K, Reiner JL, Yun SH, Perrotta EE, Tao L, Johnson-Restrepo B, Rodan BD (2005) Polycyclic musk compounds in higher trophic level aquatic organisms and humans from the United States. Chemosphere 61:693-700
Kemp PF (1987) Potential impact on bacteria of grazing by a macrofaunal deposit-feeder, and the fate of bacterial production. Mar Ecol Prog Ser 36:151-161

Klimek B, Niklinska M (2007) Zinc and copper toxicity to soil bacteria and fungi from zinc polluted and unpolluted soils: A comparative study with different types of Biolog plates. Bull Environ Contam Toxicol 78:112-117

Könemann H (1981) Quantitative structure-activity relationships in fish toxicity studies. Toxicology 19:209-221

Linke-Gamenick I, Forbes VE, Sibly RM (1999) Density-dependent effects of a toxicant on life-history traits and population dynamics of a capitellid polychaete. Mar Ecol Prog Ser 184:139-148

Linke-Gamenick I, Forbes VE, Méndez N (2000a) Effects of chronic fluoranthene exposure on sibling species of Capitella with different development modes. Mar Ecol Prog Ser 203:191-203

Linke-Gamenick I, Vismann B, Forbes VE (2000b) Effects of fluoranthene and ambient oxygen levels on survival and metabolism in the three sibling species of Capitella (Polychaete). Mar Ecol Prog Ser 194:169-177

Liu W-T, Marsh TL, Cheng H, Forney LJ (1997) Characterization of microbial diversity by determining terminal restriction fragment length polymorphisms of genes encoding $16 \mathrm{~S}$ rRNA. Appl Environ Microbiol 63:4516-4522

Lopez GR, Levinton JS (1987) Ecology of deposit-feeding animals in marine sediments. Q Rev Biol 62:235-260

Loreau M (2000) Biodiversity and ecosystem functioning: Recent theoretical advances. Oikos 91:3-17

Macnaughton SJ, Stephen JR (2001) A combined phospholipid and 16S-rDNA PCR-DGGE analysis to study bioremediative microbial communities in situ. In: Rochelle PA (ed.) Environmental molecular microbiology: Protocols and applications. Horizon Scientific Press, Wymondham, pp 141-160

Madsen SD, Forbes TL, Forbes VE (1997) Particle mixing by the polychaete Capitella species 1: Coupling fate and effect of a particle-bound organic contaminant (flouranthene) in a marine sediment. Mar Ecol Prog Ser 147:129-142

Magurran AE (2004) Measuring biological diversity. Blackwell Publishing, Oxford

Méndez N (2006) Effects of teflubenzuron on sediment processing by members of the Capitella species-complex. Environ Pollut 139:118-124

Méndez N, Romero J, Flos J (1997) Population dynamics and production of the polychaete Capitella capitata in the littoral zone of Barcelona (Spain, NW Mediterranean). J Exp Mar Biol Ecol 218:263-284

Méndez N, Linke-Gamenick I, Forbes VE, Baird DJ (2001) Sediment processing in Capitella ssp. (Polychaeta: Capitellidae): Strain-specific differences and effects of the organic toxicant fluoranthene. Mar Biol 138:311-319

Muckian L, Grant R, Doyle E, Clipson N (2007) Bacterial community structure in soils contaminated by polycyclic aromatic hydrocarbons. Chemosphere 68:1535-1541

Naeem S, Li S (1997) Biodiversity enhances ecosystem reliability. Nature 390:507-509 
Nakata H (2005) Occurrence of synthetic musk fragrances in marine mammals and sharks from Japanese coastal waters. Environ Sci Technol 39:3430-3434

Osemwengie LI, Gerstenberger SL (2004) Levels of synthetic musk compounds in municipal wastewater for potential estimation of biota exposure in receiving waters. J Environ Monit 6:533-539

Osemwengie LI, Steinberg S (2001) On-site solid-phase extraction and laboratory analysis of ultra-trace synthetic musks in municipal sewage effluent using gas chromatographymass spectrometry in the full-scan mode. J Chromatogr A 932:107-118

Osemwengie LI, Steinberg S (2003) Closed-loop stripping analysis of synthetic musk compounds from fish tissues with measurement by gas chromatography-mass spectrometry with selected-ion monitoring. J Chromatogr A 993:1-15

Paul D, Pandey G, Meier C, Van der Meer JR, Jain RK (2006) Bacterial community structure of pesticide-contaminated site and assessment of changes induced in community during bioremediation. FEMS Microbiol Ecol 57:116-127

Pedersen S, Selck H, Salvito D, Forbes V (2009) Effects of the polycyclic musk HHCB on individual- and populationlevel endpoints in Potamopyrgus antipodarum. Ecotoxicol Environ Saf 72(4):1190-1199

Petersen DG, Dahllof I, Nielsen LP (2004) Effects of zinc pyrithione and copper pyrithione on community function and structure in sediments. Environ Toxicol Chem 23:921-928

Ramskov T, Selck H, Salvito D, Forbes V (2009) Individualand population-level effects of the synthetic musk, HHCB, on the deposit-feeding polychaete, Capitella sp I Environ. Toxicol Chem 28(12):2695-2705

Romanowski G, Lorenz MG, Wackernagel W (1993) Use of polymerase chain reaction and electroporation of Escherichia coli to monitor the persistence of extracellular plasmid DNA introduced into natural soils. Appl Environ Microbiol 59:3438-3446

Salvito DT, Senna RJ, Federle TW (2002) A framework for prioritizing fragrance materials for aquatic risk assessment. Environ Toxicol Chem 21:1301-1308

Salvito DT, Vey MGH, Senna RJ (2004) Fragrance materials and their environmental impact. Flavour Fragr J 19:105-108

Selck H, Forbes VE (2004) The relative importance of water and diet for uptake and subcellular distribution of cadmium in the deposit-feeding polychaete, Capitella sp. 1. Mar Environ Res 57:261-279

Selck H, Forbes VE, Forbes TL (1998) Toxicity and toxicokenetics of cadmium in Capitella sp. I: Relative importance of water and sediment as routes of cadmium uptake. Mar Ecol Prog Ser 164:167-178

Selck H, Decho AW, Forbes V (1999) Effects of chronic metal exposure and sediment organic matter on digestive absorption efficiency of cadmium by the deposit-feeding polychaete Capitella species I. Environ Toxicol Chem 18(6):1289-1297
Selck H, Palmqvist A, Forbes VE (2003) Uptake, depuration, and toxicity of dissolved and sediment-bound fluoranthene in the polychaete Capitella sp I. Environ Toxicol Chem 22(10):2354-2363

Self RFL, Jumars PA (1978) New resource axes for deposit feeders? J Mar Res 36:627-641

Shugart LR, Theodorakis C (1996) Genetic ecotoxicology: The genotypic diversity approach. Comp Biochem Physiol 113:273-276

Simonich SL, Begley WM, Debaere G, Eckhoff WS (2000) Trace analysis of fragrance materials in wastewater and treated wastewater. Environ Sci Technol 34:959-965

Simonich SL, Federle TW, Eckhoff WS, Rottiers A, Webb S, Sabaliunas D, De Wolf W (2002) Removal of fragrance materials during U.S. and European wastewater treatment. Environ Sci Technol 36:2839-2847

Stumm W, Morgan JJ (1981) Aquatic chemistry: An introduction emphasizing chemical equilibria in natural waters. Wiley, New York

Tobor-Kaplon MA, Bloem J, Römkens PFAM, de Ruiter PC (2005) Functional stability of microbial communities in contaminated soils. Oikos 111:119-129

Tobor-Kaplon MA, Bloem J, Römkens PFAM, de Ruiter PC (2006) Functional stability of microbial communities in contaminated soils near a zinc smelter (Budel, The Netherlands). Ecotoxicology 15:187-197

Tsutsumi H (1987) Population dynamics of Capitella capitata (Polychaeta; Capitellidae) in an organically polluted cove. Mar Ecol Prog Ser 36:139-149

Tsutsumi H (1990) Population persistence of Capitella sp. (Polychaeta; Capitellidae) on a mud flat subject to environmental disturbance by organic enrichment. Mar Ecol Prog Ser 63:147-156

Van Beelen P, Doelman P (1997) Significance and application of microbial toxicity tests in assessing ecotoxicological risks of contaminants in soil and sediment. Chemosphere 34:455-499

Weinbauer MG, Fritz I, Wenderoth DF, Höfle MG (2002) Simultaneous extraction from bacterioplankton of total RNA and DNA suitable for quantitative structure and function analyses. Appl Environ Microbiol 68:1082-1087

Wolsing M, Priemé A (2004) Observation of high seasonal variation community structure of denitrifying bacteria in arable soil receiving artificial fertilizer and cattle manure by determining T-RFLP of nir gene fragments. FEMS Microbiol Ecol 48:261-271

Yingst JY, Rhoads DC (1980) The role of bioturbation in the enhancement of bacterial growth rates in marine sediments. In: Tenore KR, Coull BC (eds.) Marine benthic dynamics. University of South Carolina Press, South Carolina, pp 407-421 